\title{
Couple Collaboration in Ministry: A Pillar for the Great Commission
}

\author{
Linda Sibanda $^{1^{*}}$, Harrison Daka $^{2}$, Lestina Makowa Daka ${ }^{3}$ \\ ${ }^{I}$ Dip in Ed, B. Ed, Ba. Theology, MA in Religion \\ ${ }^{2}$ Cert in Psy Socio Counselling, Dip in Theology, BSc Ed, Postgrad Dip Med Ed, MA Ed Adm, PhD in Med Edu \\ ${ }^{3}$ Cert in Psy Socio Couselling, Cert in Food and Nutrition, Bsc Nursing
}

*Corresponding Author: Linda Sibanda, Dip in Ed, B. Ed, Ba. Theology, MA in Religion, Zambia

\begin{abstract}
The kind gospel transformation can only take place when gender roles are upheld. Moreover, the Great Commission can only have its true effect when humanity obey all what scripture say about men and women's roles. In his wisdom, God designed his Spirit-indwelt children to find gender-specific niches in His family and in doing this the Great Commission is advanced. To neglect this is to reject the whole counsel of what is said in scripture and the need to rightly reflect in our marriages and homes the gospel of Jesus Christ. This is absolutely essential. Focusing on the need for marital conformity to the Great Commission is an instruction from the Lord as it challenges christian husbands and wives to consider their marital orientation and to ask how the two are contributing to fulfilling the Great Commission. When the two marry, the great commission must be the central aim of their marriage. The great commission must become the one thing that sets the agenda for everything else. Jesus promised to all those who believe in him, that by His Spirit we would be bold witnesses (Acts 1:8). Practically speaking, you can consider your "Jerusalem" to be your family and local church. This reality is true personally and in marriage. Serving as a couple has benefits that go beyond bonding, contentment and peace. There's a special nice intimacy that comes with working together especially in helping those in need. Couples who embrace God's call to serve others experience an added closeness, and there are special moments and memories that naturally come when you do things together. In addition, participating together in ministry opportunities can also help you to grow in your faith as a couple. Working side-by-side to fulfill the Great Commission deepens your spiritual intimacy. Above all, being the Lord's witnesses by serving, giving, encouraging, caring and loving is rewarding beyond words. But in the end, it's not really about you as a couple but those who need a touch from God. Whenever you serve others, you become the hands and feet of your Savior. The Spirit of Christ will grant grace and wisdom to fulfill the task of winning the nations, through husbands who lead their families to love the kingdom of Christ and wives who come alongside their men to help accomplish the task.
\end{abstract}

Keywords: Great Commission, Church growth, Couple, Collaboration

\section{INTRODUCTION}

The family impacts on the growth of every member and plays an important role in the functional operation of a social system. Pastoring is among the few most respected and trusted professions. Therefore, members of society trust pastors with their problems and other traumatic experiences. These engagements with congregants usually are not restricted by time boundaries, as congregants expect the pastor to be available at all times (Dai and Wang, (2015). As a result, one can not underestimate the role of the spouse or the pastors' wife or husband as she automatically fills in the large void left by the pastor at home as he/she attends to his/her congregants. The spouses of pastors seem to have additional roles other than their normal roles.

Many spouses do not feel God has called them specifically but they feel called to the man or woman. It is therefore, prudent that both the pastor and the spouse are sufficiently prepared for the calling. There must be total commitment and agreement before they both embark on this journey of ministry. This is essential because they have to instantly understand that the journey of ministry requires a lot of sacrifice (James, 2009). It is for this reason that they must always endeavor to ensure that they work as a team.

Teamwork between the two is very important for various reasons. What the pastor may forget to do of crucial matter, the spouse can always remind. Having known the strength and weakness of each other 
they can be able to strengthen one another where the other is weak so much so that the weakness may be covered up. This will help to bring out only the strengths. This would establish a balanced ministry. The women will feel covered by the ministry of their pastor's spouse and the men will be encouraged to receive the ministry of their fellow man in their homes. If a minister and companion can jointly engage in visitation. So everyone will have someone they can freely identify with. If possible children can also accompany their parents in their visitations. In the process they can befriend their friends and bring them to Christ.

\section{COllaboration In THE GODHEAD}

The Godhead reveals the team work between the Father, Son and the Holy Spirit. In fact, in the Godhead is obvious that three are better than one in comparison to "two are better than one" (Ecclesiastes 4:9). There is also reliance among the Trinity. The plan of salvation would never have been accomplished if one of the team members had not done his duties. The three work together as a team. Jesus said that, "I and my Father are one" (John 10:30). This means that they have the same purpose, power and authority. There is no inferiority between the Father, Son and the Holy Spirit.

The Godhead plays a variety of roles. There is a teaching in the bible that, "the head of Christ is God" (1Corinthians 11:3). The Bible reveals that Jesus Christ fulfills an important function, "who, being in the form of God, did not consider it robbery to be equal with God, but made Himself of no status, taking the form of a bondservant, and coming in the likeness of men. "And being found in form as a man, he humbled Himself and became obedient to the point of death, even the death of the cross" (Philippians 2:6-8).

Humanity is saved through Jesus Christ bringing them to the father. The saved are brought into a bond with the Godhead through the death of Jesus Christ at the cross of Calvary. The bible reveals God as the lover, the judge and the initiator. John says, "For God so loved the world, that he gave his only begotten son, that whosoever believes in him shall not perish but have an everlasting life." (John $3: 16$ ). The father took the duty of sending the son, this is revealed in the words of Jesus, and "...my meat is to do the will of him that sends me and to finish his work." (John 4:34). In addition to that, it is the delight of the son to do his will. (John 8:29).Jesus the son of God is the redeemer, the mediator and the head of the church. As the redeemer, Jesus redeems God's people, "Therefore the redeemed of the Lord shall return and come with gladness unto Zion..." (Isaiah 35:10). The intercessory function of Christ is seen when he, "...made intercession for the transgressors." (Isaiah 53:12). Paul says that, "...Christ is the head of the church..." (Ephesians 5:23).

The Holy Spirit is the comforter and assistant. Jesus says that, "And I will pray to the father and he shall give you another comforter" (John 14:16). Paul says that, "Likewise the spirit also helps us in our infirmities for we know not what we should pray for..." (Romans 8:26). So the Holy Spirit is our helper. The Holy Spirit empowers and motivates. Jesus Christ the son was full of the Holy Spirit, "and Jesus being full of the Holy Ghost returned from Jordan and was led by the spirit into the wilderness." (Luke 4:1) Furthermore, "...Jesus returned in the power of the spirit into Galilee and there went out a fame of him through the entire region round about."

The Holy Spirit accompanies all the wonderful and mighty works of the ministry of Jesus. The life of Jesus Christ was characterized by prayer. Before he does things, he would pray to the Father to find out his will (Breese, 2007). The bible indicates that before choosing his disciples, he prayed ".... He went out to the mountain to pray and continued all night in prayer to God", (Luke 6:12). The communication between the father and the son was very consistent. Jesus said, "... as my father hath taught me, I speak these things." (John 8:28).

\section{Collaboration In Marriage}

Team work in marriage begins at creation when God created Adam and later on Eve who was his team mate. God gave Adam the honor to give names to the living creatures. The Bible says that, ".... but for Adam there was not found any help mate for him", (Genesis 1:20). God made Adam to sleep a deep sleep as he made a woman. When God awoke Adam from the sleep he exclaimed as he saw somebody fit to be his team mate. He said, "This is now bone of my bone, and flesh of my flesh........" (Genesis 2:23). The woman was created to be a helper.

Eve was to be a valuable team mate. A woman therefore is the perfect complement to man through marriage. Team-ship in marriage is closer than the bond between parent and child. In fact, the 
husband and wife were to leave and cleave to one another, "Therefore shall a man leave his father and mother and shall cleave unto his wife and the two shall be one flesh". (Genesis 2:24). This signifies composite unity of two people united as one in marriage. In other words, key allegiance belongs to each other above even the close bond of parent and child.

There is interdependence on each other between husband and wife. Paul says that, "Nevertheless neither is the man without the woman, neither the woman without the man in the Lord." (1 Corinthians 11:11). Paul goes on further to say that, "For the woman is of man, even so is the man also by the woman, but all things of God". (1 Corinthians11:12). The team-work in marriage requires compatibility, companionship, nearness, personal involvement and cooperation. This means you are together for life, in good times and bad times sharing joys and sorrows, burdens in sickness or health, hardship or success. There should be no pulling against each other but pulling with each other in the same direction. Teamwork in marriage is a case of me and you against the world.

\section{Conviction Of The Couple}

It is important to note that a conviction of what one is supposed to do is important for that work to be done effectively. In other words, the pastor and spouse should be convinced of the work they should do in ministry. They should have the conviction that God has placed them where they are for his pleasure and his purpose as well as for their good. Stewart (2013) added that the calling is to trust in the spirit's help to serve the Father. In other words, the pastor and spouse are not left alone in the ministry. The Holy Spirit is with them to guide them into all truth (John 16:13). It has pleased the Lord to give them the ministry and so as the owner of the ministry he will continue to guide them in how to serve him effectively.

The pastor and spouse should have a conviction that places Christ and his people above all of the leader's desires, ambitions and opinions. A good example is that of Paul when he says that, "I am crucified with Christ, nevertheless I live, yet not I, but Christ lives in me...." (Galatians 2:20). It should not be all about them but all about Christ and serving God's people. The pastor and spouse should see the ministry as service rather than a way of fulfilling and promoting themselves. The pastor and spouse should be willing to serve God in whatever capacity. They should accept any assignment necessary as long as it is advancing God's work. In other words, they need a conviction of loyalty that will save the church and the team even in challenging moments.

A conviction of faithfulness is needed for the pastor and spouse. They cannot do without it. They need to be faithful to each other and above all faithful to the Lord their God. This virtue is emphasized in the book of Revelation. John says, ".... Be faithful unto death and I will give you a crown of life..." (Revelation 2:10). The pastor and spouse should be faithful and in due season they shall receive a reward. The pastor and spouse should also have a conviction of availability. In other words, they should avail themselves to God's programs as well as God's people. Whatever God wants them to do they should be willing to do it.

\section{COUPLE'S Fulfillment OF GOD's Mission}

The pastor and shepherdess have an obligation too to fulfill the great commission. The teaching of the gospel is indeed a great charge to everyone saved including the pastors and their spouses. Dobson (2012) sees the great commission as a commission of obedience. The commission to teach necessitates faithfulness and honesty to the word of God. Jesus called his disciples to also make disciples and teach them as he had taught them. Paul obeyed to the commission to teach (Acts 19:8). Even Apollos was involved in the work to teach the word of God to the church (Acts 18:25). Priscilla and Aquila too made their contributions too in teaching the word even unto Apollos himself (Acts 18:26). The other example is of Timothy who was charged to teach others to be able to teach and preach the gospel as he had been taught by Paul (1 Timothy 2:2). It is also recognized that the Christian church has been having teachers throughout its history. There is a great need in the church for pastors and shepherdess who should be teachers of the word of God. Pastors and shepherdess should be involved in quality biblical discipleship. God has imparted his spiritual gifts so that His people may be saved into the kingdom. A good couple that exhibited this type of commission is Aquila and Priscilla.

Priscilla and Aquila practiced collaborative ministry. They worked together leading a church in their home, (Romans 16:3-5). This team was a husband and wife team who lived together, worked together 
and ministered together. Aquila and Priscilla is a model of collaboration in the New Testament. They were involved in forming, nurturing and leading house churches. These two were fellow workers in the ministry of Jesus Christ with Paul. In Romans 16:3 Paul refers to them as, "my fellow workers in Christ Jesus." Paul left these fellow workers in Christ Jesus in the city of Ephesus. One may ask a question, was Paul's act of leaving them just their separate on a going in different ways or was it Paul leaving them in the city of Ephesus as ministers under his apostolic oversight?

It is very interesting and of great significance that their names are always mentioned together in scripture as if they were inseparable. They were a good model of a beautiful team ministry based on common submission and respect. It seems that Priscilla chose to follow her sense of calling instead of limiting herself to home making. There are times that financial reality dictates that husband and wife put their efforts together to do God's work without splitting the family and resources. In this case, Priscilla and Aquila worked hand in hand not just to earn a living, but also to spread the gospel of Jesus Christ.

The names of Priscilla and Aquila appear together six times in the New Testament in early church history at Corinth, Rome and Ephesus. This reveals that they were so well travelled in major centers of Christianity. They were also prominent Christians in the history of the early church. These two offer us a valuable example of team ministry. There is something revealed about the background of the team of Priscilla and Aquila. Aquila was a Jew from Pontus in Asia Minor, (Acts 18:2). His wife Priscilla also had a Jewish background, though it is not said specifically. It is also interesting to note that the bible is silent on their conversion experience. First contact with them in Acts 18:2 may suggest that they were perhaps among Rome's first Christians. It can be assumed that they were already Christians.

Scripture states that Priscilla and Aquila were tent makers, (Romans 18:3). They belonged to the same occupation as Paul. Interesting to note this couple also had the same profession even before teaming up in ministry. Priscilla and Aquila practiced team ministry in teaching. This is revealed in an event that took place in Ephesus. It is recorded in scripture that a Jew named Apollos born at Alexandria, an eloquent man and mighty in scriptures came to Ephesus, (Acts 18:24). Apollos was instructed in the way of the Lord, he taught diligently the way of the Lord but his knowledge was limited to the baptism of John, (Acts 18:25). He spoke boldly in the synagogue. When Priscilla and Aquila heard him, they sought to teach him the way of the Lord more accurately, (Acts 18:26).

Even though no more has been said about this couple in scriptures, there is enough information to know that they played a major role in the early years of the Christian movement. They were a gifted couple who gained the admiration of the Apostle Paul. Paul calls them his "core workers in Christ Jesus," (Romans 16:3). It is interesting to note that this is a designation Paul uses to describe leaders in ministry.

The method of ministry of Aquila and Priscilla was to start churches in their homes, (1Corinthias 16:19). It's important to acknowledge that in the first years of Christianity there were no church buildings; Christian worship took place in homes. The center of life for the Christian community in a particular place was the church in a house. The early Christians met in homes to worship together and to hear the gospel preached such was the home of Priscilla and Aquila. It seems that the house church in early Christian times was simple and not extravagant probably a small room which was a part of the host's home.

Priscilla and Aquila were ministering laborers with pastor's hearts. They would not go and reach to lost souls for Christ only to be left in someone else's pastoral care but where ever they went they would establish a church. They must have believed in the community. To them the gospel was not an individual matter, it also had a social dimension, and Priscilla and Aquila were a husband and wife team concerned with building Christian communities among believers.

\section{COMPlementary For The Great COMMission}

In 1 Corinthians 11: 2, the Apostle Paul writes, "Christ is the head of every man, and the man is the head of the woman". Peter also says, "wives, be submissive to your own husbands" (1 Pet. 3:1), commending them to be daughters of Sarah who showed her husband respect and deference by calling him "lord." Even if the world lives to turn the Bible on its head and rejects these teachings in passionate unbelief, the scriptural portrait is undeniable. Men and women are equal, yet distinct. 
Both were made in the image of God, they are co-heirs; nevertheless in their roles and natural relations they are different. Husbands are to lead and wives are to help. The man's good works are uniquely masculine, while the woman also displays a particular feminine conformity into the image of Christ. And in the Great Commission, these roles are not to be undermined but rather as mutually distinctive partners, both can, should, and must complement one another in the work, not compete for one another's place of service.

The point is, Jesus' Great Commission is not a sex-less enterprise but is fulfilled by redeemed men and women who are shaped by the Spirit into distinctly masculine and feminine representatives of the kingdom. Though cross-gender evangelism is frequent and fruitful, this is not the same thing as biblical discipleship. Men need godly men to whom they can pattern their lives, and women need mature females to train them in domestic holiness. Likewise, we must realize that the evangelistic task is not simply about winning disconnected individuals to the Lord but to see families get saved. When this happens, relationships are built, roles are revived, the household of God flourishes, and the glory of the gospel is seen. The gospel then does more than give eternal life to the transsexual male who flees from their former lifestyle, it completes its task by "restoring the hearts of the fathers to their children and the hearts of children to their fathers" (Mal. 4:6).

Aquila and Priscilla worked together in their tent-making business, and they served together in ministry. When we operate as a team in things like housework, childcare or exercise, we can make tasks in our married life seem easier and more rewarding. Likewise, collaborating with our spouse in spiritual disciplines can strengthen our walk with Christ, as well as strengthen our marriage. As individuals we grow spiritually through prayer, Bible study, and engagement in our church community and service. As couples we can grow even more when we do these things together.

\section{COMmon ObStacles to COllaborative Ministry}

It is worth noting that there are common obstacles to collaborative work as couple to fulfil the Great Commission. It is important to note that as a pastor and spouse work together as a team, there are common obstacles they meet along the way.

i. One of these obstacles is trust. It is very crucial as well as discretion. The pastor and spouse should guard against misspoken words that may make people lose such as can lead the pastor and spouse to go through certain trials in their ministry. This calls the pastor and spouse to use wisdom in choosing their friends too. Senter (2005) gives caution that a pastor and spouse should be friend to all and close companion to none. This comes as a result of so many challenges that come because of some unworthy relationships. It is important for the pastor and spouse to love everyone and relate well with all of them but take caution if any would take advantage of their love and trust and kindness.

Trust also plays an important big role between the pastor and spouse. For them to work together there should be trust. They may need to trust each other to be able to cover each other's weaknesses. Byler $(2008 ; 197)$ says that, "we have many other differences that can send us in diverse directions." So trust is foundational to a team and it comes with a willingness to be vulnerable. The other person should not betray the other as they work together as a team. It is important for pastor and spouse team to build trust as they get to know each other and also learning to acknowledge individual strengths for the pastor and spouse to consider if they are trust worthy and to build it up over time since there are no shortcuts.

ii. Lack of Communication. Lack of communication comes as another obstacle between a pastor and spouse. This comes because the pastor and spouse are two people who think differently and may put across their ideas differently or sometimes decide to keep certain information to themselves. Malphurs (2005) advocates for openness in communication. This means that there should be no hiding of any information in communication.

It should be noted that issues can arise between the pastor and spouse regarding communication. It can be miscommunication, either a lack of communication or bad communication. Sometimes a pastor or spouse may be hurt or they may feel that they have not been heard or even not been given information at all. In such cases the couple should take the earliest opportunity to sit down and discuss issues. It is usually best to have no intermediary but to speak directly one to one another. Face to face communication is very important. It is 
important to deal with personal issues that can affect the team of the pastor and spouse, to talk about it and clear the air between the two.

iii. Lack of growth is another obstacle. Individual growth is also important for the pastor and spouse. Even as they grow as a team it is important for them to spend time individually with the Lord. Byler (2008) said that for collaboration to function well, each one must to do their part in individual growth for the both to function well. This means that even as the pastor and spouse work together as a team each should put their maximum effort. They should also make an effort to grow together. If the pastor and spouse do not grow, the church will also be affected. They can learn to work together more effectively, manage time better, to trust each other more and focus on the strength of the other as they grow and develop.

\section{Principles for Collaborative Ministry in the Great Commission}

After understanding the obstacles to collaborative ministry, let us now look at the principles on which the two rely upon for effective ministry. It is imperative for the pastor and spouse to allow God to define their ministry. It usually happens that people have an idea of the ministry of the pastor and spouse and also their duties. It should be recalled that God calls and equips his servants. God leads the pastor and spouse in the way in which they should work for him. In all your ways, acknowledge him he will direct your ways (Proverbs 3:6). The following are some of the principles.

\section{i. Open to encouragement and criticism.}

It is an important principle of pastor and spouse to communicate more than they think. Byler (2008) said that clear communication builds teams. Indeed, clear communication will bring less misunderstanding since each person will understand what they should do and in that way the team will be built. Marlphurs (2005) also adds that both they feel free to express thoughts and emotions without there being a hint of a threat or reprisal. Such free and open communication it is important for the pastor and spouse ministry. In addition to that, Leith and Jill $(2015 ; 118)$ says that in communication, "welcome questions and comments". Through questions and comments the pastor and spouse might realize other deeper understandings that are helpful in their ministry and also areas where they need to improve. When they communicate well they will be able to work better. That will contribute to the success of the ministry.

\section{ii. Never bring Conflict Home}

The other principle is that the pastor and spouse should not bring conflict home. They should not dump conflict, negative feelings or anger over difficult people on the spouse. It matters how one handles conflict. It should be resolved in the church as much as possible and not at home. When something has been resolved, it is important to accept the situation and not to breed negative feelings or anger. It is good to make a home a place of rest and not a place of solving conflicts.

Anger should be resolved on a daily basis. It should not be allowed to build up because if allowed, it can burst out and destroy relationships completely. It should be noted that few factors contribute more to relational deterioration than unresolved anger. One should learn to forgive, forget and move on with life. It is also important when your spouse is frustrated with you to listen to your partner, ask for forgiveness even if you are not completely to blame. One should realize that your ministry and your flock depend on it.

\section{iii. Rest, Exercise and Eat Health}

One other principle of teamwork between pastors and their spouses is to rest, exercise and eat healthy as well as to drink enough water. Cooper (2016) said that with adequate hydration blood can flow easily throughout the body, providing much needed oxygen and nutrition. This means that the body should not be deprived of water because water plays a very big role in the body. One would even say that we are water containers because our body weight is made up of a high percentage of water. It is important for the couple to take time to rest. They need to have enough hours to sleep and also to eat food that will not lead to other health complications.

\section{iv. Network Support System}

It is important for the pastor and spouse to build a support system of friends with whom you can share difficulties and struggles. Indeed, the network of friends is very important. What is most important is 
the caliber of those friends. They should be people who will encourage and strengthen one in the Lord. Carson $(2005$; 157) says that, "Remember that the spiritual forces of the evil one are tasked with the assignment of preventing the work of God from moving forward". In order for the work of God to move forward the support network should pray and fast so that the devil and his angels are defeated. You need trusted and faithful intercessors. It is true that no one is an island. Human beings need each other, to support and encourage one another. In moments of crisis they should be there for one another. The pastor and spouse team needs the effort of others to advance the kingdom of God.

\section{v. Balance use of Finances}

There must be a balance in the use of your finances. It is important to set boundaries between your ministry and your personal finances. If the couple is not careful that can lead to a lot of family stress and conflicts. By managing your finances, you can avoid worry and financial uncertainty. However, the pastor and spouse should be faithful in giving their tithes and offerings. Holford (2016) points that every marriage needs a balance of wise saving, wise spending and wise sharing or giving. It is needless to say that to strike a balance in spending finances the couple needs careful planning. It would be helpful for the pastor and spouse to talk about their finances together. It is important to agree on what can be spent on household purchases with, and without, the other person's consent. This will reduce the financial stress between the pastor and spouse. It will also make it easy for each one of them to spend on other small personal items as well as special gifts for one another.

\section{vi. Know each Other}

It is important for a pastor and spouse to know each other very well. This includes personality, talents, gifts, preferences and relational skills. It is important for the pastor and spouse to help each other realize all the potential that God has given them both. In that vein each should appreciate the potential of the person God has teamed them with. Malphurs (2005) advises couples to share personal history, including the bad along with the good. This will help the pastor and spouse to understand each other better since they will have the knowledge of each other's history. It is important to identify and discuss the strengths, weaknesses and limitations. When one knows the strengths and weaknesses of their partner, they will know how to handle them better. They can be able to bear those weaknesses better unlike when they come as a shock to them. Also they will be able to cover up for each other's weaknesses. The knowledge of each other's limitation of temperament will also help your partner to chip in and strike a balance even in the conversation and other situations.

\section{CONCLUSION}

The pastor and spouse were created by God for the specific purpose of serving him. God regards them as a team. They can collaborate up right from their marriage in their family life as well as in the church. It may not be however in everything but there are specific areas where the pastor and spouse may collaborate up. For them to team up well they need to know the purpose of their team, common challenges in pastor and spouse team; principles of team ministry as well as their conviction and ideas about team ministry including team ministry in teaching and fulfillment of God's commission.

\section{REFERENCES}

[1] Byler, J. (2008). The Art of Christian Leadership, Developing Skills to Lead God's people. Lancaster, PA: Global Disciples.

[2] Bresee, F. W. (2007). Pastor's Pastor: Husband-wife team ministry.International Journal for Pastors .10 (2), 12 - 24.

[3] Carson, P. (2005). Mentoring Leaders. Grand Rapids, Michigan: Baker Books.

[4] Cooper, R. L. (2016). To keep you alive. Drink when you drive. The Journal. A resource for Ministry Spouses (33): 11 .

[5] Dai, L. \& Wang, L (2015). Review of Family Functions The Relationship Doctors, Prescription for Better Communication in Your Marriage. Open Journal of Social Sciences, 3(1), 101 - 123.

[6] Dobson, J. K. (2012). Gospel Discipleship. Wheaton, IL: Crossway.

[7] Holford, K. (2016). Money, Money. The Journal, A resource for Ministry spouses (33) 21.

[8] James, K. (2009). Evangelism Explosion. Wheaton, IL: Tyndal House Publishers.

[9] Leith, A. \& Jill, F. (2015). The Volunteer Church. Grand Rapids, Michigan: Zondersvan. 
[10] Malphurs, A. (2005). Advanced Planning: A new model for church and ministry leaders. 2nd Edition. Grand Rapids, Michigan: Baker Books

[11] Senter, R. (2005). So you're the pastor's wife. Grand Rapids, MI: Zondervan.

[12] Stewart, C.J. (2013). Letters to Pastor's Wives: When Seminary Ends and Ministry Begins. Phillipsbuerg, NJ: P \& R Publishers.

Citation: Linda Sibanda, et.al. "Couple Collaboration in Ministry: A Pillar for the Great Commission" International Journal of Humanities Social Sciences and Education (IJHSSE), vol 8, no. 4, 2021, pp. 26-33. doi: https://doi.org/10.20431/2349-0381.0804004.

Copyright: (C) 2021 Authors. This is an open-access article distributed under the terms of the Creative Commons Attribution License, which permits unrestricted use, distribution, and reproduction in any medium, provided the original author and source are credited. 